\title{
Pengembangan Perangkat Pembelajaran Berdasar Masalah dengan Pendekatan Saintifik pada Materi Segi Empat Kelas VII SMP
}

Nurul Wahidatul Kistatuhu', Mega Teguh Budiarto ${ }^{2}$, Siti Khabibah $^{3}$

1,2,3 Universitas Negeri Surabaya, Indonesia

E-mail: $\underline{\text { nurulkista1@gmail.com, megatbudiarto@unesa.ac.id, sitikhabibah@unesa.ac.id }}$

\begin{tabular}{l} 
Article Info \\
\hline Article History \\
Received: $2021-10-09$ \\
Revised: 2021-11-02 \\
Published: 2021-11-27
\end{tabular}

Keywords:

Problem based learning; Scientific approach; Quadrilateral.

\begin{abstract}
This study aims to: (1) describe of process and results the development of problem based learning with scientific approach device on quadrilateral lesson for seventh grade students; (2) describe effectiveness learning of problem based learning with scientific approach device on quadrilateral lesson for seventh grade students. This research was conducted in two stages, the development stage which following the design of the 4-D model and experimental stage. The results show that the scientific approach devices are good quality because they met valid, practical, and effective criteria. The validity aspect are fulfilled based on validation result get a minimum score of 3 for each aspect and assesment test met valid, reliable, and sensitive. Practical aspects are fulfilled based on teacher activities in a good kategory and the level of student activity reaches $95.6 \%$. The aspect of effectiveness is fulfilled based on the result of classical learning completeness showed $83 \%$ and the student's positive response to the device reaches $92 \%$. The effectiveness of learning shows effective based on teacher activity in good kategory, the level of student activity in learning reaches $96.4 \%$, the student's positive response to the learning reaches $93 \%$, the result of classical learning completeness showed $89 \%$.
\end{abstract}

\begin{tabular}{l}
\hline Artikel Info \\
\hline Sejarah Artikel \\
Diterima: $2021-10-09$ \\
Direvisi: 2021-11-02 \\
Dipublikasi: 2021-11-27
\end{tabular}

Kata kunci:

Pembelajaran berdasar masalah;

Pendekatan saintifik; Segiempat.

\begin{abstract}
Abstrak
Penelitian ini bertujuan untuk: (1) mendeskripsikan proses dan hasil pengembangan perangkat pembelajaran berdasar masalah dengan pendekatan saintifik pada materi segiempat kelas VII SMP yang baik; (2) mendeskripsikan keefektifan pembelajaran berdasar masalah dengan pendekatan saintifik pada materi segiempat kelas VII SMP. Penelitian ini dilaksanakan dalam dua tahap, yaitu tahap pengembangan yang mengikuti rancangan model 4-D dilanjutkan dengan tahap eksperimen. Hasil penelitian menunjukkan bahwa produk yang dikembangkan berkualitas baik karena memenuhi kriteria valid, praktis, dan efektif. Perangkat memenuhi kriteria valid berdasarkan hasil penilaian validator yang mendapatkan skor minimal 3 pada setiap aspek serta tes hasil belajar memenuhi kriteria valid, reliabel, dan sensitif. Perangkat memenuhi kriteria praktis berdasarkan aktivitas guru dalam kategori baik dan tingkat keaktifan siswa mencapai 95,6\%. Perangkat memenuhi kriteria efektif berdasarkan ketuntasan hasil belajar siswa yang mencapai 83\% serta respon positif siswa terhadap perangkat mencapai $92 \%$. Sedangkan pembelajaran menunjukkan capaian efektif didasarkan pada aktivitas guru berkategori baik, tingkat keaktifan siswa dalam pembelajaran mencapai $96,4 \%$, respon positif siswa terhadap pembelajaran mencapai 93\%, dan ketuntasan belajar siswa mencapai 89\%.
\end{abstract}

\section{PENDAHULUAN}

Matematika merupakan ilmu dasar yang mempunyai peranan penting dalam upaya menguasai ilmu pengetahuan dan teknologi. Karena itu matematika mempunyai karakteristik sebagai ilmu abstrak. Sehingga dalam kegiatan pembelajaran, guru tidak bisa langsung mentransfer pengetahuan matematika secara utuh ke dalam pikiran siswa. Untuk dapat memahami matematika dibutuhkan pengertian, pemahaman, dan keterampilan secara mendalam terhadap materi yang sedang dipelajari. Sehingga tak dapat dipungkiri bahwa sebagian siswa masih menganggap matematika sebagai mata pelajaran yang sulit. Anggapan tersebut tentu mempengaruhi capaian hasil belajar matematika siswa, salah satu materi yang daianggap sulit adalah geometri, padahal, mempelajari geometri sangatlah penting, hal ini dikarenakan geometri memiliki peranan yang sangat banyak bagi kehidupan sehari-hari. Hal ini didukung oleh pendapat Özerem (2012) bahwa mempelajari geometri adalah komponen yang penting dalam belajar matematika dikarenakan siswa diarahkan untuk menganalisa dan menginterpretasikan dunia sebagai tempat tinggalnya dan mempersiapkan siswa untuk dapat menggunakannya dalam ranah lain selain matematika. Salah satu 
materi geometri dikelas VII SMP adalah segiempat. Materi segiempat ini cukup penting dipelajari karena penggunaan konsep segiempat dalam kehidupan sehari-hari sangat banyak, misalnya menghitung luas tanah, keliling kebun dan sebagainya.

Namun, kenyataannya penguasaan siswa tentang geometri terutama segiempat masih lemah. Seperti yang diungkapkan oleh Özerem (2012) bahwa miskonsepsi siswa terhadap geometri disebabkan oleh pengajaran dan pembelajaran yang berpusat pada guru dan buku teks. Akibatnya, siswa harus melihat, mendengarkan, menulis catatan, dan berfikir dalam proses pembelajarannya. Mereka harus memperhatikan banyak sekali elemen pembelajaran dan memasukkannya ke dalam memori mereka. Hal tersebut sering mengakibatkan proses berfikir mereka menjadi berlebihan dan menyebabkan efek negatif terhadap proses belajar yang dilakukan oleh siswa tersebut. Hal ini didukung oleh fakta yang terjadi dilapangan bahwa proses pembelajaran yang dilakukan guru masih menggunakan metode konvensional yaitu menjelaskan, memberi contoh, dan memberi latiha soal. Pembelajaran seperti ini cenderung monoton dan hanya berlangsung satu arah sehingga siswa cenderung pasif selama proses pembelajaran. Siswa masih tergantung dengan penjelasan guru untuk membangun pengetahuannya dan harus dibimbing serta diarahkan untuk menghubungkan satu materi dengan materi lainnya. Oleh karena itu diperlukan skenario pembelajaran yang tepat sehingga siswa terfasilitasi untuk mengonstruk pengetahuan dan pemahamannya sendiri dalam memecahkan masalah menggunakan konsep segiempat.

Salah satu pembelajaran yang dapat digunakan adalah pembelajaran berdasar masalah dengan pendekatan saintifik. Pembelajaran berbasis masalah melibatkan siswa dengan suatu masalah yang otentik dan bermakna yang dapat berfungsi sebagai batu loncatan untuk penyelidikan (Arends, 2009). Selanjutnya Duch, Groh, \& Allen (2001) menyatakan bahwa pada pembelajaran berdasar masalah, masalahmasalah kompleks dan nyata digunakan untuk memotivasi siswa dalam mengidentifikasi dan menelaah konsep dan prinsip yang mereka butuhkan untuk mengetahui penyelesaian masalah tersebut. Dengan demikian pembelajaran berdasar masalah merupakan pembelajaran yang berpusat pada siswa dengan menggunakan masalah sebagai konteks untuk melaksanakan penyelidikan sehingga siswa aktif mengontruksi pengetahuan yang dimilikinya. Sedangkan peran guru dalam Pembelajaran Berdasar Masalah adalah memberikan permasalahan nyata, memfasilitasi penyelidikan dan mendukung pembelajaran siswa. Dalam hal ini siswa dituntut untuk mampu menyelesaikan permasalahan yang autentik dengan tujuan untuk mengembangkan pengetahuan yang dimilikinya sedangkan guru berperan sebagai fasilitator.

Sedangkan pendekatan saintifik dikatakan tepat karena dapat mengarahkan siswa untuk menemukan sendiri berbagai fakta dan membangun konsep khususnya pada materi segiempat secara langsung pada tiap aktivitas pembelajarannya, pendekatan saintifik merupakan sebuah pendekatan pembelajaran yang dirancang sedemikian rupa agar siswa secara aktif mengonstruk konsep, prinsip melalui tahapan-tahapan mengamati, merumuskan masalah, mengajukan hipotesis, mengumpulkan data, menganalisis data, menarik kesimpulan dan mengomunikasikan konsep, hukum atau prinsip yang ditemukan (Hosnan, 2014). Melalui pendekatan ini, sesuai dengan Permendikbud Nomor 54 Tahun 2013, peserta didik diharapkan memiliki kemampuan pikir dan tindak yang produktif dan kreatif dalam ranah abstrak dan konkret sesuai dengan yang ditugaskan padanya. Oleh karena itu, pendekatan saintifik dalam pembelajarannya seharusnya dilakukan dengan baik.

Pembelajaran berbasis masalah dengan pendekatan saintifik sama-sama menggunakan suatu masalah dalam pembelajarannya, pada pembelajaran berdasar masalah dimulai dengan adalah masalah nyata dan pendekatan saintifik pembelajarannya menggunakan masalah yang dapat dinalar oleh siswa Sehingga melalui kombinasi dari kedua model pembelajaran tersebut diyakini dapat menghasilkan suatu proses pembelajaran yang melibatkan siswa secara penuh selama proses pembelajaran dalam menyelesaikan permasalahan matematika berdasarkan konteks dalam kehidupan sehari-hari.

\section{METODE PENELITIAN}

Penelitian ini merupakan penelitian pengembangan. Model pengembangan yang digunakan dalam penelitian ini adalah model pengembangan Four-D yang dikembangakan oleh (Thiagarajan, Semmel, \& Semmel, 1920) Model pengembangan Four-D meliputi empat tahapan yaitu pendefinisian (define), perancangan (design), pengembangan (develop) dan 
penyebaran (disseminate). Adapun pera-ngkat pembelajaran yang dikembangkan adalah RPP, LKS, dan THB.

A. Subjek dan Waktu Penelitian

Subjek dalam penelitian ini adalah siswa kelas VII SMPN 3 Kras yang terdiri dari dua kelas. Kelas VII-D digunakan sebagai kelas uji coba perangkat sedangkan kelas VII-A dijadikan sebagai kelas eksperimen yang bertujuan untuk mengetahui efektifitas pembelajaran berdasar masalah dengan pendekatan saintifik, adapun penelitian ini dilaksanakan pada semester genap tahun ajaran 2018/2019.

B. Instrumen Pengumpulan Data

Instrumen dalam penelitian ini digunakan untuk mengumpulkan data kevalidan, kepraktisan, keefektifan dan keefektifan pembelajaran. Instrumen penilaian kevalidan meliputi lembar validasi RPP, lembar validasi LKS, lembar validasi THB dan analisis THB. Instrumen penilaian kepraktisan meliputi lembar pengamatan aktivitas guru dan lembar pengamatan aktivitas siswa dalam pembelajaran. Instrumen penilaian kefektifan meliputi angket respon siswa terhadap perangkat dan penilaian THB. Sedangkan instrumen keefektifan pembelajaran meliputi lembar pengamatan aktivitas guru dalam pembelajaran, lembar pengamatan aktivitas siswa dalam pembelajaran, respon siswa, dan penilaian hasil belajar.

C. Analisis Data

Teknik analisa data dalam penelitian ini secara rinci meliputi teknik analisa data kevalidan, kepraktisan, kefektifan, dan keefektifan pembelajaran, analisis data kevalidan diperoleh dari hasil validasi perangkat oleh validator, selanjutnya, dilakukan penghitungan rata-rata skor pada setiap aspek dan dibandingkan dengan selang kriteria pada tabel 1 berikut:

Tabel 1. Kriteria Validasi Perangkat Pembelajaran

\begin{tabular}{cl}
\hline Skor Nilai & Kriteria \\
\hline $1,00 \leq x<1,75$ & Tidak baik \\
\hline $1,75 \leq x<2,50$ & Kurang baik \\
\hline $2,50 \leq x<3,25$ & Baik \\
\hline $3,25 \leq x<4,20$ & Sangat Baik \\
\hline
\end{tabular}

THB dianalisis secara deskriptif untuk mengetahui validitas, reliabilitas, dan sensitivitas soal. Validitas butir soal di uji menggunakan statistik product moment (Arikunto, 2010) sebagai berikut:

$$
r_{X Y}=\frac{N \sum_{i=1}^{N} X_{i} Y_{i}-\left(\sum_{i=1}^{N} X_{i}\right)\left(\sum_{i=1}^{N} Y_{i}\right)}{\sqrt{\left\{N \sum_{i=1}^{N} X_{i}^{2}-\left(\sum_{i=1}^{N} X_{i}\right)^{2}\right\}\left\{N \sum_{i=1}^{N} Y_{i}^{2}-\left(\sum_{i=1}^{N} Y_{i}\right)^{2}\right\}}}
$$

Keterangan:

$r_{X Y}=$ koefisien validitas $r$

$N$ = banyaknya subjek uji coba

$X=$ skor tes/nilai tes

$Y \quad=$ skor kriteria/nilai kriteria

Nilai $r_{x y}$ diinterpretasikan pada Tabel 2 berikut:

Tabel 2. Kriteria Validitas Instrumen

\begin{tabular}{ll}
\hline Koefisien Validitas & Kriteria Validitas \\
\hline $0,80<r_{x y} \leq 1,00$ & Sangat Tinggi \\
\hline $0,60<r_{x y} \leq 0,80$ & Tinggi \\
\hline $0,40<r_{x y} \leq 0,60$ & Sedang \\
\hline $0,20<r_{x y} \leq 0,40$ & Rendah \\
\hline $0,00<r_{x y} \leq 0,20$ & Sangat Rendah \\
\hline$r_{x y} \leq 0,00$ & Tidak Valid \\
\hline
\end{tabular}

Reliabilitas tes ditentukan dengan menggunakan rumus Alpha (Arikunto, 2010) sebagai berikut:

$$
r_{11}=\left(\frac{k}{k-1}\right)\left(1-\frac{\sum_{i=1}^{n} \sigma_{i}^{2}}{\sigma_{t}^{2}}\right)
$$

\section{Keterangan:}

$r_{11}=$ reliabilitas tes secara keseluruhan

$\sum \sigma_{i}{ }^{2}=$ jumlah varians skor tiap-tiap butir

$\sigma_{t}^{2}=$ varians total

$K$ = banyaknya butir pertanyaan

$N$ = banyaknya responden

$\sum x=$ jumlah skor item

$\sum x^{2}=$ jumlah kuadrat skor item

Reliabilitas diinterpresentasikan pada Tabel 3 berikut:

Tabel 3. Kriteria Reliabilitas Tes

\begin{tabular}{ll}
\hline Skor Nilai & Kriteria Reliabilitas \\
\hline $0,80<r_{11} \leq 1,00$ & Sangat Tinggi \\
\hline $0,60<r_{11} \leq 0,80$ & Tinggi \\
\hline $0,40<r_{11} \leq 0,60$ & Sedang \\
\hline $0,20<r_{11} \leq 0,40$ & Rendah \\
\hline $0,00<r_{11} \leq 0,20$ & Sangat Rendah \\
\hline$r_{11} \leq 0,00$ & Tidak Reliabel \\
\hline
\end{tabular}

Sedangkan rumus sensitivitas butir soal menurut (Gronlund, 2011) sebagai berikut.

$$
S=\frac{\sum_{i}^{n} S_{e s}-\sum_{i}^{n} S_{e b}}{N\left(s k o r_{\max }-s k o r_{\min }\right)}
$$


Keterangan :

$S \quad=\quad$ Indeks sensitivitas butir

$N \quad=\quad$ Banyaknya siswa yang mengikuti tes awal dan tes akhir

$\sum_{i}^{n} S_{e s} \quad=\quad$ Jumlah skor subjek setelah proses pembelajaran

$\sum_{i}^{n} S_{e b}=$ Jumlah skor subjek sebelum proses pembelajaran

. Skor $_{\text {max }} .=$ Skor maksimal yang dicapai subjek

$. S k o r_{\min } .=$. Skor minimal yang dicapai subjek

Dalam penelitian ini butir soal dikatakan valid dan reliabel jika mempunyai koefisien validitas dan reliabilitas minimal sedang. Sedangkan butir soal dikatakan baik jika sensitivitasnya berada diantara 0 dan 1 , Analisis data kepraktisan diperoleh dari aktivitas guru dalam mengelola pembelajaran dan aktivitas siswa dalam pembelajaran. Analisis data kemampuan guru mengelola pembeljaran dilakukan dengan mencarai ratarata tiap kategori pada setiap aspek kemudian dibandingkan dengan selang kriteria pada Tabel 4 berikut:

Tabel 4. Tingkat Kemampuan Guru dalam Mengelola Pembelajaran

\begin{tabular}{cl}
\hline Skor Nilai & Kriteria \\
\hline $1,00 \leq x<1,75$ & Tidak baik \\
\hline $1,75 \leq x<2,50$ & Kurang baik \\
\hline $2,50 \leq x<3,25$ & Baik \\
\hline $3,25 \leq x<4,20$ & Sangat Baik \\
\hline
\end{tabular}

Sedangkan aktifitas siswa dikatakan baik jika semua aspek pengamatan terlaksana dengan baik. Kriteria penilaian aktivitas siswa selama pembelajaran menggunakan interval yang disajikan pada Tabel 5 berikut:

Tabel 5. Persentase Aktivitas Siswa Dalam Pembelajaran

\begin{tabular}{ll}
\hline Persentase Aktivitas & Kriteria \\
\hline Aktivitas $<65 \%$ & Todak Aktif \\
\hline $65 \% \leq$ Aktivitas $<80 \%$ & Kurang Aktif \\
\hline $80 \% \leq$ Aktivitas $<95 \%$ & Aktif \\
\hline $95 \% \leq$ Aktivitas & Sangat Aktif \\
\hline
\end{tabular}

Analisis data keefektifan perangkat diperoleh dari respon siswa dan ketuntasan klasikal belajar siswa. Respon siswa tercapai jika $80 \%$ siswa memberikan respon positif terhadap perangkat pembelajaran. Sedangkan ketuntasan secara klasikal terpenihi jika 75\% siswa mencapai ketuntasan secara individual, keefektifan pembelajaran terpenihi jika aktivitas guru dalam proses pembelajaran berkategori baik, aktivitas siswa dalam pembelajaran berkategori aktif, respon siswa dalam pembelajaran positif serta ketuntasan belajar klasikal mencapai 75\%.

\section{HASIL DAN PEMBAHASAN}

\section{A. Hasil Penelitian}

Penelitian ini menggunakan pengembangan model 4-D yang terdiri dari empat tahapan pengembangan, yaitu pendefinisian (define), perancangan (design), pengembangan (develop), dan penyebaran (disseminate), pada tahap pendefinisian (define) dilakukan analisis awal-akhir, analisis siswa, analisis konsep, analisis tugas, dan spesifikasi tujuan pembelajaran. Analisis awal akhir dilakukan dengan cara observasi dan wawancara guru bidang studi matematika. Dari hasil tersebut diketahui beberapa permasalahan dalam proses pembelajaran matematika, yaitu: (1) pembelajaran masih berpusat pada guru, dimana guru lebih sering memberikan materi dan contoh soal untuk dikerjakan oleh siswa. (2) guru memberikan rumus secara langsung tanpa memberikan penjelasan yang mendasari pembuktian rumus tersebut. (3) guru belum pernah mengembangkan perangkat pembelajaran seperti LKS dan RPP untuk menerapkan model pembelajaran yang berbeda. Dengan demikian diperlukan pembelajaran yang berpusat pada siswa dan menempatkan guru sebagai salah satu fasilitator dengan cara menerapkan pembelajaran berdasar masalah dengan pendekatan saintifik sebagai salah satu solusinya.

Analisis siswa yang dilakukan meliputi latar belakang perkembangan kognitif dan kemampuan akademik. Secara umum hasil analisis siswa diperoleh sebagai berikut: (1) siswa kelas VII-A dan VII-D SMP N 3 Kras ratarata berusia 13-15 tahun. Jika dikaitkan dengan tahap perkembangan kognitif Piaget (Schunk, 2012), maka siswa tersebut berada pada tahap operasional formal dimana anak sudah mampu berfikir secara abstrak. Sehingga pembelajaran dapat dilakukan dengan menyajikan permasalasahan yang berkaitan dengan kehidupan sehari-hari. (2) Berdasarkan hasil wawancara yang dilakukan dengan guru matematika diperoleh informasi bahwa siswa kelas VII-A dan VII-D memiliki kemampuan beragam, yaitu berkemampuan 
tinggi, berkemampuan sedang dan berkemampuan rendah.

Analisis konsep dalam penelitian ini adalah konsep yang berkaitan dengan segiempat yaitu pada pokok bahasan jajar genjang dan trapesium yang mengacu pada kurikulum 2013, adapun sub materi yang digunakan dalam penelitian ini adalah keliling dan luas bangun jajar genjang dan trapezium, analisis tugas dalam penelitian ini dilakukan sebagai dasar menyususn tugas-tugas yang harus dilakukan dan diselesaikan oleh siswa dalam proses pembelajaran. Secara umum kegiatan siswa dan rincian tugas siswa dalam pembelajaran matematika meliputi: (1) mengamati permasalahan yang disajikan untuk mengidentifikasi hal-hal yang ingin diketahui. (2) mengajukan pertanyaan terkait permasalah yang belum dipahami. (3) melakukan kegiatan percobaan sesui petunjuk. (4) mengaitkan informasi yang diperoleh dari kegiatan percobaan untuk menyelesaikan masalah. (5) bertukar informasi terkait hasil yang diperoleh.

Spesifikasi tujuan pembelajaran dibuat berdasarkan indikator dari analisis konsep dan analisis materi. Secara umum spesifikasi tujuan pembelajaran dalam penelitian ini antara lain: (1) menemukan rumus keliling dan luas jajar genjang. (2) menyelesaikan masalah yang berkaitan dengan keliling dan luas jajar genjang. (3) menemukan rumus keliling dan luas trapesium. (4) menyelesaikan masalah yang berkaitan dengan keliling dan luas trapesium.

Tahap pencanaan (design) dilakukan pemilihan media, pemilihan format, dan perancangan awal perangkat pembelajaran. Pemilihan media dalam penelitian ini disesuaikan dengan analisis tugas, analisis konsep, dan karakteristik siswa. Adapun media yang digunakan dalam penelitian ini adalah LKS sedangkan alat bantu yang diperlukan terdiri dari papan tulis, HVS, spidol warna, lem, dan penggaris. Pemilihan media ini digunakan untuk mengoptimalkan penggunaan bahan ajar pada pembelajaran dikelas.

Format dan karakeristik perangkat pembelajaran matematika yang dikembangkan adalah sebagai berikut: (1) RPP yang digunakan disesuaikan dengan format RPP pada kurikulum 2013 dan mengikuti langkahlangkah dalam pembelajaran berdasar masalah dan saintifik. (2) LKS disusun berdasarkan pembelajaran berdasar masalah dan saintifik. Sedangkan isi LKS mengacu pada hasil analisis konsep, analisis tugas, dan spesifikasi tujuan pembelajaran yang telah dirumuskan. (3) THB disusun berdasarkan spesifikisai tujuan pembelajaran untuk materi yang berkaitan dengan jajar genjang dan trapesium.

Perancangan awal dalam penelitian ini meliputi perancangan terhadap produk awal yaitu RPP, LKS, dan THB. Perangkat yang dirancang pada tahap ini disebut draft 1. RPP disusun untuk 2 kali pertemuan dengan alokasi waktu $2 \times$ pertemuan. Alokasi waktu yang digunakan adalah $2 \times 40$ menit untuk setiap pertemuan. LKS disusun untuk $2 \times$ pertemuan dengan rincian (1) LKS 1 membahas keliling dan luas jajar genjang. (2) LKS 2 membahas keliling dan luas trapesium. THB yang disusun berbentuk tes uraian yang berisi 4 butir soal. Sedangkan waktu yang digunakan untuk menyelesaikan soal adalah 80 menit. Penyususnan THB juga dilengkapi dengan penyusunan kisi-kisi butir soal, kunci jawaban dan pedoman penskoran. Perangkat pembelajaran yang disusun pada tahap ini disebut dengan draft 1.

Pada tahap pengembangan (develop) kegiatan yang dilakuakan adalah validasi ahli, uji keterbacaan dan uji coba perangkat. Pada tahap validasi draft 1 yang telah disusun kemudian divalidasi oleh validator menggunakan lembar validasi yang disusun oleh peneliti. Dalam penelitian ini validator terdiri dari 2 orang dosen matematika dan satu guru matematika SMP N 3 Kras. Berdasarkan hasil validasi, dapat disimpulkan bahwa perangkat yang dikembangkan valid dan siap digunakan untuk uji coba dengan menambahkan beberapa saran dari validator. Saran dari validator menjadi dasar untuk melakukan revisi produk. Produk yang sudah di revisi dan divalidasi disebut draft 2 . Hasil validasi perangkat dapat dilihat pada Tabel 6 berikut.

Tabel 6. Hasil Validasi Perangkat

\begin{tabular}{lll}
\hline No. & Produk & Kevalidan \\
\hline 1. & RPP & Valid \\
\hline 2. & LKS & Valid \\
\hline 3. & THB & Valid \\
\hline
\end{tabular}

Sebelum diuji cobakan draft 2 lebih dulu di uji keterbacaannya. Hal ini bertujuan apakah perangkat yang disusun sudah dapat terbaca dengan jelas dan dapat dipahami sehingga dapat digunakan pada kelas yang menjadi subjek penelitian. Uji keterbacaan LKS dan 
THB dilakukan pada 6 siswa yang memiliki kemampuan berbeda. Dalam hal ini siswa diminta menadai kata atau kalimat yang tidak dipahami. Uji keterbacaan juga dilakukan pada guru mitra dengan cara membaca serta memahami perangkat kemudian menuliskan atau menyampaikan hal-hal yang kurang dimengerti. Berdasarkan hasil uji keterbacaan diperoleh bahwa siswa dan guru mitra memahami dengan jelas maksud dan tujuan dari setiap kallimat yang tertera pada perangkat pembelajaran sehingga tidak perlu direvisi dan selanjutnya dapat diuji cobakan.

Uji coba perangkat dilakukan untuk mengetahui apakah perangkat yang dikembangkan berkualitas baik yaitu memenuhi kriteria valid, praktis dan efektif. Uji coba ini melibatkan guru dan siswa. Dari segi guru, uji coba melibatkan dua guru matematika sebagai guru mitra dan pengamat. Sedangkan dari segi siswa, uji coba dilakuakan pada kelas VII-D SMP N 3 Kras yang terdiri dari 35 siswa.

Uji coba dilaksanakan selama 4 kali pertemuan. Dalam uji coba ini, siswa dibagi menjadi 6 kelompok yang beranggotakan 5-6 siswa dengan kemampuan yang berbeda. Sebelum dilakukan uji coba siswa diberi pre test terlebih dahulu untuk mengetahui kemampuan awal siswa. Kemudian dilakukan proses pembelajaran dengan menggunakan perangkat yang dikembangkan. Selama proses pembelajaran dilakukan pengamatan terhadap aktivitas guru dan siswa oleh pengamat. Setelah proses pembelajaran berakhir, siswa diberikan post test untuk mengetahui penguasaan siswa terhadap materi setelah diberi perlakuan.

Berdasarkan hasil uji coba diperoleh bahwa (1) rata-rata aktivitas guru pada setiap aspek yang dinilai mencapai $\geq 3.5$ yang berarti bahwa aktivitas guru pada proses pembelajaran berada pada kategori sangat baik. Hal ini menunjukkan bahwa sebagian aktivitas guru sudah sesuai dengan RPP. (2) rata-rata aktivitas siswa selama proses pembelajaran adalah 96,9\%. Dengan demikian dapat dikatakan bahwa siswa aktif dalam pembelajaran. (3) respon siswa terhadap perangkat pembelajaran mencapai 92,14\%. Sehingga dapat disimpulkan bahwa perangkat pembelajaran mendapatkan respon positif dari siswa (4) tes hasil belajar siswa memenuhi kriteria valid, reliabel dan sensitif. (5) ketuntasan klasikal siswa mencapai 83\%.
Berdasarkan hasil pada tahap perancangan dan pengembangan diperoleh bahwa perangkat pembelajaran yang disusun memenuhi kriteria valid praktis dan efektif sehingga perangkat pembelajaran yang disusun dapat disebut sebagai perangkat pembelajaran yang baik.

Tahap terakhir adalah tahap penyebaran (disseminate). Pada tahap ini penyebaran dilakukan sangat terbatas karena kemampuan peneliti, biaya, waktu, kesempatan dan kecenderungan administrasi yang rumit. Penyebaran hanya dilakukan di satu kelas lain tempat peneliti melakukan uji coba yaitu dikelas eksperimen kelas VII-A.

Eksperimen pembelajaran bertujuan untuk mengetahui efektifitas pembelajaran menggunakan perangkat yang berkualiatas baik. Eksperimen ini melibatkan guru dan siswa. Dari segi guru, ekperimen ini melibatkan dua guru matematika sebagai guru mitra dan pengamat. Sedangkan dari segi siswa, uji coba dilakuakan pada kelas VII-A SMP N 3 Kras yang terdiri dari 36 siswa, eksperimen pembelajaran dilaksanakan selama 4 kali pertemuan. Dalam pembelajaran ini, siswa dibagi menjadi 6 kelompok yang beranggotakan 5-6 siswa dengan kemampuan yang berbeda. Proses pembelajaran yang dilakuakn dengan menggunakan perangkat yang berkualiatas baik. Selama proses pembelajaran dilakukan pengamatan terhadap aktivitas guru dan siswa oleh pengamat. Setelah proses pembelajaran berakhir, siswa diberikan post test untuk mengetahui efektifitas pembelajaran mengggunakan perangkat yang baik.

Berdasarkan hasil eksperimen pembelajaran diperoleh bahwa (1) rata-rata aktivitas guru pada setiap aspek yang dinilai mencapai $\geq 3$ yang berarti bahwa aktivitas guru pada proses pembelajaran berada pada kategori baik. Hal ini menunjukkan bahwa sebagian aktivitas guru sudah sesuai dengan RPP. (2) rata-rata aktivitas siswa selama proses pembelajaran adalah 96,4\%. Dengan demikian dapat dikatakan bahwa siswa aktif dalam pembelajaran. (3) respon siswa terhadap perangkat pembelajaran mencapai 93,69\%. Sehingga dapat disimpulkan bahwa perangkat pembelajaran mendapatkan respon positif dari siswa (4) ketuntasan klasikal siswa mencapai 89\%, berdasarkan hasil pada eksperimen pembelajaran diperoleh bahwa pembelajaran menggunakan perangkat yang 
berkualitas baik pada materi jajar genjang dan trapesium berlangsung efektif.

\section{B. Pembahasan}

Pembahasan difokuskan pada mengaitkan data dan hasil analisisnya dengan permasalahan atau tujuan penelitian dan konteks teoretis yang lebih luas. Dapat juga pembahasan merupakan jawaban pertanyaan mengapa ditemukan fakta seperti pada data?, pembahasan bukan sekadar menarasikan data. Urutan pembahasan selaras urutan sajian data: cocokkan hipotesis/harapan dengan data. Berikan analisis atau tafsiran. Kembangkan gagasan atau argumentasi dengan mengaitkan hasil/ teori/ pendapat/ temuan sebelumnya, a.l. dengan membandingkan dengan temuan terdahulu, adakah pertimbangan teoretis, adakah kemungkinan manfaat, dan adakah kemungkinan keterbatasan hasil. Kembangkan argumen dalam paragraf. Isi pada bagian ini lebih-kurang 35\% dari total halaman naskah.

Produk yang dihasilkan dalam penelitian ini adalah perangkat pembelajaran berdasar masalah pada materi segiempat yang meliputi RPP, LKS, dan THB. Berdasarkan penilaian validator terhadap perangkat yang dikembangkan ditinjau dari aspek format, isi, dan bahasa semua dalam kategori baik dan dapat digunakan dengan menambahkan beberapa yang diberikan oleh validator. perangkat yang sudah divalidasi dilakukan uji keterbacaan pada guru dan siswa untuk mengetahui apakah perangkat yang disusun sudah dapat terbaca dengan jelas dan dapat dipahami sehingga dapat digunakan pada kelas yang menjadi subjek penelitian. Dari hsail uji keterbacaan perangkat yang dikembangkan dapat terbaca jelas oleh guru dan siswa sehingga tidak perlu direvisi.

Tahap selanjutnya setelah uji keterbacaan adalah uji coba. Uji coba dilakukan pada kelas VII-D yang terdiri dari 35 siswa untuk mendapatkan kriteria kepraktisan dan keefektifan perangkat pembelajaran, berdasarkan proses dan hasil diperoleh bahwa aktivitas guru dalam melakukan pembelajaran pada setiap aspek yang dinilai mencapai $\geq 3.5$ yang berarti bahwa aktivitas guru pada proses pembelajaran berada pada kategori sangat baik, dengan demikian perangkat pembelajaran mudah digunakan oleh guru. Hal ini sesuai dengan pendapat (Nieven, 1999) bahwa perangkat pembelajaran dikatakan praktis jika perangkat tersebut mudah untuk digunakan oleh guru maupun siswa.

Hasil pengamatan pada aktivitas selama proses pembelajaran menunjukkan bahwa siswa turut berperan aktif dalam pembelajaran. Hal ini sesuai dengan teori Vygotsky (Schunk, 2012) yang menyatakan bahwa interaksi sosial siswa dalam kelompok dan guru dapat membantu siswa untuk membentuk pengetahuan mereka, hasil analisis pada THB diperoleh bahwa THB termasuk dalam kategori valid, reliabel, dan sensitif. Adapun butir soal dengan tingakat validitas tinggi adalah butir soal nomor 1,3, dan 4. Adapun butir soal dengan validitas sangat tinggi adalah soal nomor 2. Sedangkan tingkat reliabilitas soal mencapai 0,62 yang termasuk dalam kategori tinggi. Sedangkan sensitifitas butir soal termasuk dalam kategori sensitif dengan tingkat sensitifitas mencapai $\geq 0.3$ hal tersebut sesuai dengan pendapat (Nieven, 1999) bahwa THB dikatakan valid, selain penilaian yang baik dari validator juga harus memenuhi kriteria valid, reliabel, dan sensitif.

Berdasarkan data hasil respon siswa terhadap perangkat pembelajaran menunjukkan bahwa respon positif siswa terhadap perangkat pembelajaran mencapai $89 \%$, hal ini berarti perangkat pembelajaran dapat diterima oleh siswa dengan baik. Hal ini sesuai dengan pendapat Nieveen (1999) bahwa perangkat pembelajaran yang baik ditunjukkan oleh respon positif siswa terhadap perangkat pembelajaran, dengan demikian dapat disimpulkan bahwa perangkat pembelajaran yang dikembangkan dalam penelitian ini memenuhi kriteria perangkat yang baik yaitu valid, praktis dan efektif. Validitas perangkat diperoleh dari hasil validasi oleh validator yang berkategori baik dan THB yang dikembangkan memenuhi kategori valid, praktis dan efektif, Perangkat yang praktis diperoleh karena aktivitas guru dan siswa berkategori aktif. Sedangkan perangkat efektif dikarenakan respon siswa terhadap perangkat positif dan ketuntasan belajar siswa mencapai 83\%.

Pembelajaran pada kelas eksperimen memenuhi kriteria efektif. Hal ini ditunjukkan oleh aktivitas guru dalam pembelajaran berkategori baik. Hal ini sesuai dengan pendapat (Aubyn, 2008) bahwa efektivitas pembelajaran mempertimbangkan dua kemungkinan yaitu kemampuan guru dalam 
melaksanakan pembelajaran dan hasil yang diperoleh siswa. Dari hasil analisis aktivitas guru dalam mengelola pembelajaran diketahui bahwa aktivitas guru untuk setiap aspek mendapatkan nilai minimal 3. Dengan kata lain, guru mampu bertindak sebagai fasilitator serta memberikan bimbingan jika terdapat siswa yang mengalami kesulitan.

Berdasarkan hasil pengamatan, aktivitas siswa selama proses pembelajaran di kelas eksperimen menunjukkan bahwa siswa sudah aktif dengan rata-rata mencapai 96,4\%. Dengan demikian dapat dikatakan bahwa siswa aktif dalam pembelajaran. Hal ini sesuai dengan pendapat (Eggen \& Kauchak, 2012) bahwa pembelajaran dikatakan efektif jika siswa secara aktif dilibatkan dalam pembelajaran, sehingga siswa tidak hanya menerima pengetahuan secara pasif tetapi juga terlibat aktif dalam pembelajaran.

Respon siswa terhadap pembelajaran menunjukkan respon positif dengan persentase mencapai 93,69\%. Sehingga dapat disimpulkan bahwa pembelajaran berdasar masalah dengan pendekatan saintifik mendapatkan respon positif dari siswa. Hal ini sesuai dengan pendapat Nieveen (1999) bahwa pembelajaran yang baik ditunjukkan oleh respon positif siswa terhadap perangkat pembelajaran.

Berdasarkan hasil analisis THB diperoleh bahwa 32 dari 36 siswa kelas VII-A mencapai ketuntasan belajar dengan nilai $\geq 75$. Dengan demikian, $89 \%$ siswa telah mencapai ketuntasan belajar. Hal ini sesuai dengan pendapat (Kemp, Morrison, \& Ross, 1991) bahwa aktvitas siswa lebih menekankan pada pencapaian tujuan pembelajaran dalam waktu yang telah ditentukan, dalam hal ini tujuan pembelajaran dapat dilihat dari ketuntasan siwa dalam mepelajari suatu materi yang ditunjukkan oleh ketuntasan belajar klasikal siswa, dengan demikian dapat disimpulkan bahwa pembelajaran berdasar masalah dengan pendekatan saintifik dalam penelitian ini memenuhi kriteria efektif. Hal ini ditunjukkan dengan aktivitas guru dalam pembelajaran berkategori baik, aktivitas siswa dalam pembelajaran efektif, respon siswa terhadap pembelajaran positif dan persentase ketuntasan belajar secara klasikal mencapai $89 \%$

\section{SIMPULAN DAN SARAN}

\section{A. Simpulan}

Berdasarkan hasil penelitian, dapat diperoleh simpulan sebagai beriku: (1) proses pengembangan perangkat pembelajaran berdasar masalah dengan pendekatan saintifik menggunakan model 4-D yang meliputi 4 tahap yaitu yaitu pendefinisian (define), perancangan (design), pengembangan (develop), dan penyebaran (disseminate). Adapun hasil dari tahap ini diperoleh produk yang berkualitas baik yaitu memenuhi ktiteria valid, praktis dan efektif. (2) pembelajaran berdasar berdasar masalah dengan pendekatan saintifikpada kelas eksperimen memenuhi kriteria pembelajaran yang efektif.

\section{B. Saran}

Saran pemanfaatan produk yang dikembangkan sebagai berikut: (1) Produk yang dihasilkan dalam penelitian ini dapat digunakan sebagai alternatif perangkat dalam mengajarkan materi segiempat kelas VII SMP. (2) Produk yang dikembangkan dapat dijadikan sebagai referensi dan bahan masukan bagi para guru untuk mengembangkan perangkat pembelajaran matematika pada materi yang lain. (3) Bagi peneliti yang lain, produk yang dihasilkan dapat digunakan sebagai acuan untuk penelitian selanjutnya

\section{DAFTAR RUJUKAN}

Arends, R. (2009). Learning to Teach (Ninth Edit). New York: McGraw-Hill.

Arikunto, S. (2010). Prosedur Penelitian Suatu Pendekatan Praktik. Jakarta: Rineka Cipta.

Aubyn, M. (2008). Study on the efficiency and effectiveness of public spending on tertiary education Third report (second draft). https://doi.org/10.2765/30348

Duch, B., Groh, S., \& Allen, D. (2001). The Power Of Problem Based Learning. Virginia: Stylush Publishing.

Eggen, P., \& Kauchak, D. (2012). Strategi dan Model Pembelajarabn. Jakarta: PT. Indeks.

Gronlund, N. (2011). Constructing Achievement Tests. In Educational Evaluation: Classic Works of Ralph W. Tyler. https://doi.org/10.1007/978-94-009-2679$\underline{03}$ 
Hosnan. (2014). Pendekatan Saintifik dan Kontekstual dalam Pembelajaran Abad 21. In Ghalia Indonesia. Bogor: Ghalia Indah.

Kemp, J., Morrison, G., \& Ross, S. (1991). Designing Effective Instruction (sixth edition). United States: Mcmillan College.

Nieven, N. (1999). Design Approaches and Tools in Education and Training. https://doi.org/10.1007/978-94-011-42557

Özerem, A. (2012). Misconceptions In Geometry And Suggested Solutions For Seventh Grade Students. Procedia - Social and Behavioral Sciences, $\quad 55, \quad 720-729$. https://doi.org/10.1016/j.sbspro.2012.09.5 57
Schunk, D. (2012). Learning Theories. In Allyn \& Bacon (Sixth Edit). New York: Allyn \& Bacon.

Thiagarajan, S., Semmel, D., \& Semmel, M. (1920). Instructional Development for Training Teachers of Exceptional. Bloomington: Indiana University. 